\title{
Ureteral metastasis of a prostatic adenocarcinoma
}

\author{
Renan Javier Otta, MD; ${ }^{*}$ Carlos Gordillo, $M D ;^{\dagger}$ Inmaculada Fernández, MD, PhD* \\ *Department of Urology, Hospital Universitario La Princesa, Madrid, Spain; 'Department of Pathology, Hospital Universitario La Princesa, Madrid, Spain
}

Cite as: Can Urol Assoc J 2015;9(3-4):e153-5. http://dx.doi.org/10.5489/cuaj.2500

Published online March 11, 2015.

\begin{abstract}
The ureter is a rare location of metastasis for any kind of primary tumour. The first case of truly ureteral metastasis was described by Stow in 1909. Regarding prostatic metastasis, the frequency is much lower with only 43 cases reported in the last century. We present a case of an exceedingly rare ureteral metastasis of a prostatic adenocarcinoma. In spite of its low incidence, it should be considered in patients with ureteral obstruction and concurrent prostatic adenocarcinoma.
\end{abstract}

\section{Introduction}

The ureter is a rare location of metastasis for any kind of primary tumour. The first case of truly ureteral metastasis was described by Stow in 1909. ${ }^{1}$ Since then, only about 400 cases have been recorded. ${ }^{2-4}$ Most of the cases have been diagnosed based on autopsy findings. In 1933 Kirshbaum found 5 cases; $^{5}$ in 1956 MacLean and Fowler described 18 cases; ${ }^{6}$ and in 1974 Cohen and colleagues found ureteral metastasis in 31 patients. ${ }^{7}$ Radiography testing has greatly increased the rate of incidental findings. Regarding to the primary tumour, half of the cases were from the breast or colorectum. Prostate cancer and uterine cervical cancer are responsible for $30 \%$ to $40 \%$ of cases, and stomach and lung cancer are reported in the remaining cases. ${ }^{4}$

The incidence of prostatic metastasis is very low, with only 43 cases reported in the last century. ${ }^{8}$ We report a new case of a true ureteral metastasis of prostatic adenocarcinoma.

\section{Case description}

We describe a case of a 65-year-old male with a history of prostatic adenocarcinoma pT3aN0M0 gleason $7(3+4)$ treated with radical prostatectomy with free surgical margins in February 2004 (initial prostate-specific antigen [PSA] $6.79 \mathrm{ng} / \mathrm{dL}$ ). The patient developed biochemical recurrence in August 2005 (PSA $0.35 \mathrm{ng} / \mathrm{dL}$ ) and was treated with external radiotherapy (70 gy) associated with hormonal therapy. In February 2008, his PSA rose progressively (PSA $2 \mathrm{ng} / \mathrm{dL}$ ). A computed tomography (CT) scan was performed and revealed para-aortic adenopathy and bone metastasis in the iliac bone and lumbar vertebrae (PSA $9.75 \mathrm{ng} / \mathrm{dL}$ ). Multiple hormonal maneuvers were attempted and finally in November 2009 chemotherapy was offered (8 cycles of docetaxel + prednisone) with partial response (PSA $17.2 \mathrm{ng} / \mathrm{dL}$ to $5 \mathrm{ng} / \mathrm{dL}$ post-chemotherapy). In January 2011 progression was observed, so a new cycle of docetaxel + prednisone (7 cycles) was attempted with partial response (PSA $136 \mathrm{ng} / \mathrm{dL}$ to $33 \mathrm{ng} / \mathrm{dL}$ ). In November 2011 further progression was detected and cabazitaxel (9 cycles) was offered (PSA $128 \mathrm{ng} / \mathrm{dL}$ to $45 \mathrm{ng} / \mathrm{dL}$ ) with partial response. In December 2012 a new cycle of cabazitaxel was administered due to further progression (PSA $224 \mathrm{ng} / \mathrm{dL}$ to $28 \mathrm{ng} / \mathrm{dL}$ ).

In September 2013, left hydronephrosis due to a ureteral lesion in the lower third was detected in a CT scan. These findings suggested primary ureteral malignancy since there were no adenopathies in the surrounding area. Urine cytologies were negative and the PSA value at that time was $10 \mathrm{ng} /$ dL. Ureteroscopy was performed. Retrograde pyelography showed stricture of the ureter of about $3 \mathrm{~cm}$. Ureteroscopy depicted ureteral lesions that were biopsied (Fig. 1). Finally a double J stent was placed.

Pathological report described prostate adenocarcinoma. Histologically a piece of tissue partially coated by the urothelium was observed (Fig. 2a). The corium shows an atypical 


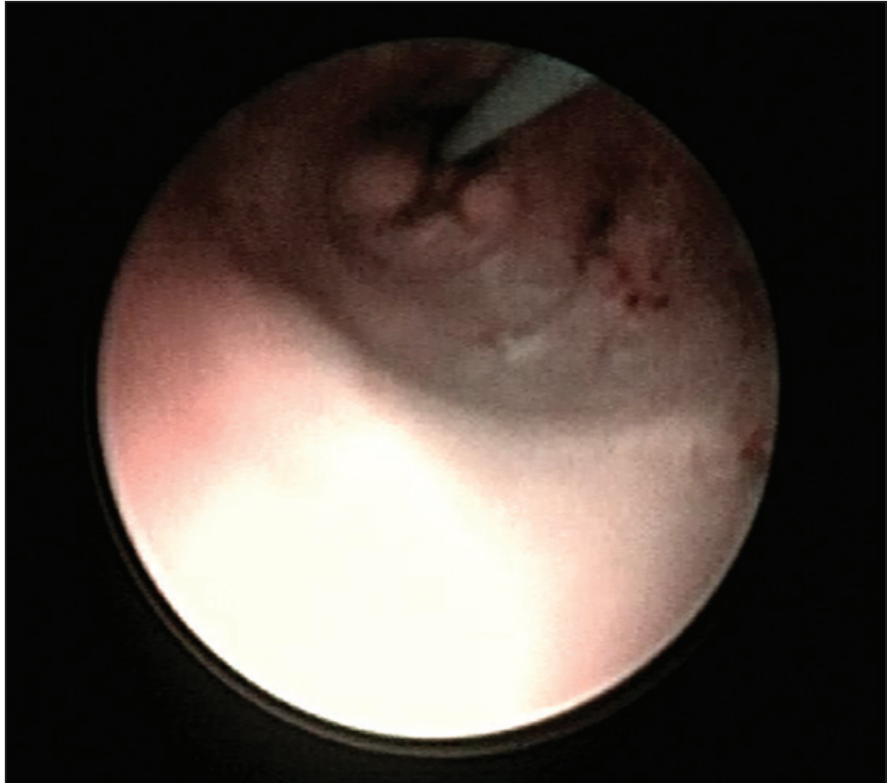

Fig. 1. Endoscopic view of the metastasis.

cell proliferation which was arranged in an infiltrating pattern of nests and single cells with irregular hyperchromatic nuclei and evident nucleolus (Fig. 2b). Immunohistochemical study was performed on paraffin-embedded tissue with anti-PSA rabbit polyclonal primary antibody, cytokeratins and P-63. The tumour cells showed mostly weak cytoplasmic positivity for PSA (Fig. 2c) being negative for cytokeratins and P-63, thus we confirmed the diagnosis of ureteral wall infiltration by primary prostate adenocarcinoma. Currently the patient is alive with cancer progression despite treatment with abiraterone (PSA $119.66 \mathrm{ng} / \mathrm{dL}$ ). Renal function is still preserved and periodical exchange of double $\mathrm{J}$ stent is performed.

\section{Discussion}

Ureteral metastasis is a rare event regardless of the primary tumour. True ureteral metastases from prostatic adenocarcinoma are exceedingly rare, with only 43 cases reported in the last century. ${ }^{8}$ In 1941, Lazarus outlined the criteria to define a true ureteral metastasis: distance between the primary tumour and metastasis, identical cellularity between the two tumours, and the presence of malignant cell emboli in the vasculature and lymphatics of the ureteral wall. ${ }^{3}$ In our case the patient fulfilled the first two criteria; we considered it a true metastasis since there were no adenopathies or other metastatic sites in the surrounding area.

Clinical presentation includes a variety of symptoms including hematuria, acute urinary retention, and flank pain. Patients are usually diagnosed with metastatic disease or locally advanced disease. Singh and colleagues reported two cases of ureteral metastasis: one case with a Gleason 8 and a PSA of $30 \mathrm{ng} / \mathrm{dL}$ at diagnosis; and the other one with a Gleason 9

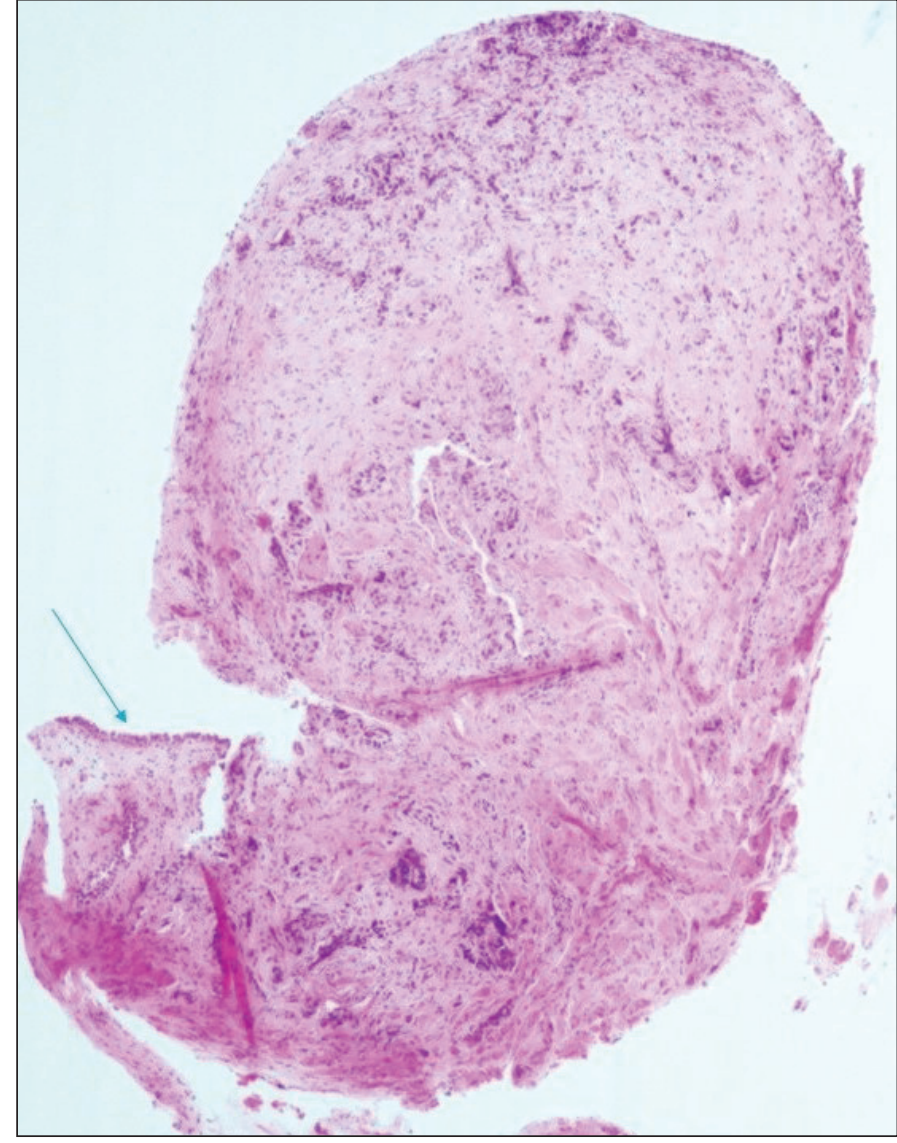

Fig. 2a. Photomicrograph obtained from ureteral biopsy. Hematoxylin and eosin stain stained section revealed a fragment of the ureteral wall partially coated by urothelium (blue arrow). The corium shows a tumour cell proliferation with an infiltrating pattern (original magnification $\times 40$ ).

(4+5) and a PSA of $502 \mathrm{ng} / \mathrm{dL} .{ }^{9}$ Hulse and O'Neill reported a case of an 82-year-old man with ureteral metastasis associated with ureteral stone. ${ }^{10}$ Jung and colleagues described the case of a 64-year-old man with ureteral metastasis secondary to prostatic adenocarcinoma $(\mathrm{T} 3 \mathrm{cN} 1 \mathrm{Mb}) 4$ years after orchiectomy. ${ }^{11} \mathrm{~A}$ most recent report is from Schneider and colleagues who described a 74-year-old patient with lower urinary tract symptoms and intermittent flank pain, skeletal metastasis, and right hydronephrosis (Gleason $7[3+4]$ and a PSA of $52 \mathrm{ng} / \mathrm{dL}$ ). Ureteroscopy with biopsy rendered ureteral metastasis of prostatic adenocarcinoma. ${ }^{8}$

Proposed hypothesis to explain the mechanism of metastasis include implantation by instrumentation, arterial embo$\mathrm{li}$, and venous or lymphatic dissemination in a retrograde manner $^{9}$ - the latter is the most accepted. The rarity of this type of spread is due to lymphatic circulation of the ureter which is segmental with no continuous lymphatic network in the ureteral wall or periureteral sheath draining directly from the prostate. ${ }^{10}$ 


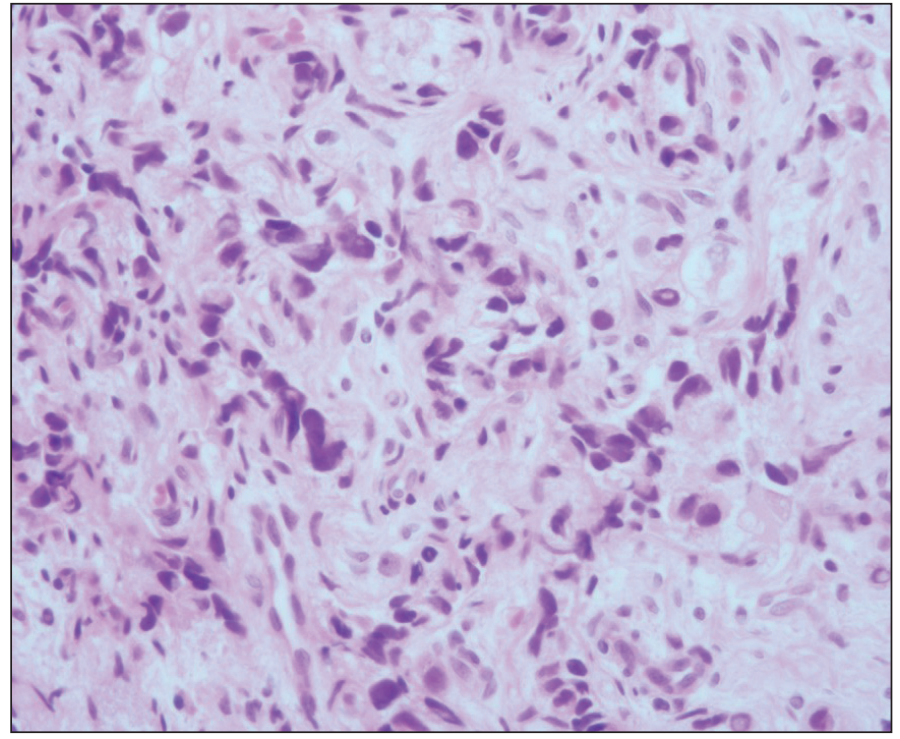

Fig. 2 b. Subepithelial connective tissue infiltrated by tumour cells arranged in a pattern of nests and single cell with irregular and hyperchromatic nuclei some with patent nucleolus (hematoxylin and eosin original magnification $\times 400$ ).

\section{Conclusion}

In our case the clinical presentation was insidious and it was detected at follow-up of a castration-resistant prostate adenocarcinoma. Unlike most cases, our case did not present with a metastatic disease or hydronephrosis at diagnosis. Furthermore, it seems that the PSA was not related to this finding (PSA at the time of hydronephrosis was $10 \mathrm{ng} / \mathrm{dL}$ ). Treatment includes nephroureterectomy, segmental resection, and conservative approaches, such as stents or nephrostomy. In our case the patient preferred double J stenting with good results.

Competing interests: Authors declare no competing financial or personal interests.

This paper has been peer-reviewed.

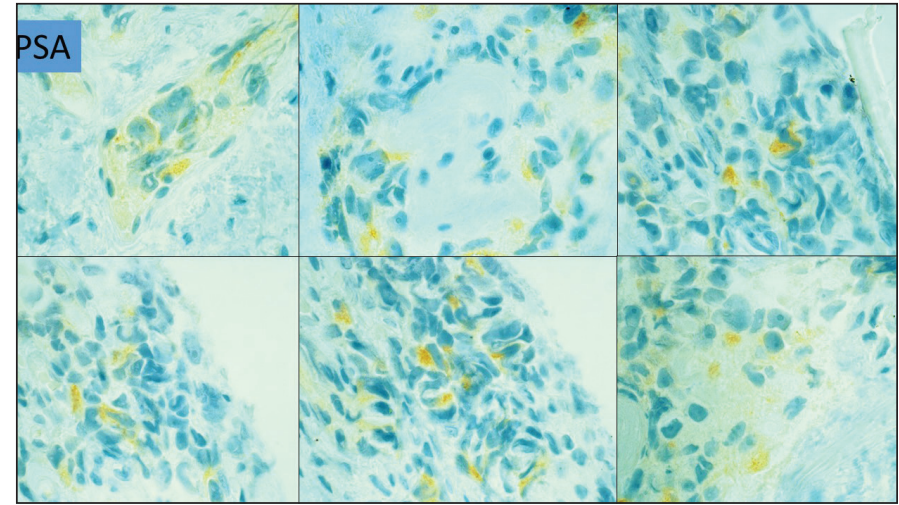

Fig. 2c. Immunohistochemical staining revealed the vast majority of tumour cells in different areas weak cytoplasmic positivity for prostate-specific antigen (original magnification $\times 1000$ ).

\section{References}

1. Stow B. Fibrolymphosarcomata of both ureters metastatic to a primary lymphosarcoma of the anterior mediastinum of thymus origin. Ann Surg 1909;14:901. http://dx.doi.org/10.1097/00000658190911000-00009

2. Haddad FS. Metastases to the ureter. Review of the world literature, and three new case reports. Journal Medical Libanais 1999:47:265-71.

3. Cortadellas R, Prieto V, Castellanos R, et al. Metástasis ureteral de adenocarcinoma prostático. Revisión de la literatura. Arch Esp de Urol 1989;42:19-22.

4. Arvind NK, Singh 0 , Gupta $\mathrm{S}$, et al. Ureteral metastasis as the presenting manifestation of pancreatic adenocarcinoma. Rev Urol 2013;15:124-30.

5. Kirshbaum JD. Metastatic tumors of ureters. J Urol 1933;30:665-77.

6. Maclean JT, Fowler VB. Pathology of tumors of the renal pelvis and ureter. J Urol 1956;75:384.

7. Cohen WM, Freed SZ, Hasson J. Metastatic cancer to the ureter: A review of the literature and case presentations. J Urol 1974;112:188-9.

8. Schneider S, Popp D, Denzinger S, et al. A rare location of metastasis from prostate cancer: Hydronephrosis associated with ureteral metastasis. Adv Urol 2012;2012:656023.

9. Singh G, Tiong HY, Kalbit T, et al. Urothelial metastasis in prostate adenocarcinoma. AAMS 2009;38:1701 .

10. Hulse $C A, O^{\prime} N$ eill TK. Adenocarcinoma of the prostate metastatic to the ureter with an associated ureteral stone. J Urol 1989; 142:1312-3.

11. Jung JY, Kim HK, Roh YT, et al. Long-standing ureteral metastasis secondary to adenocarcinoma of the prostate after bilateral orchiectomy. J Urol 2000;164:1298-9. http://dx.doi.org/10.1016/S0022$5347(05) 67163-7$

Correspondence: Dr. Renan Javier Otta, Department of Urology, Hospital Universitario La Princesa, Madrid, Spain; renan44@gmail.com 